\title{
Improving Wheat Productivity by Application Types Different of Fertilizer under Newly Reclaimed Soil Conditions
}

\author{
F.S. Abd El-Samie, M.O.A. Rady, A.H.A. Mahdi" and Yosra and M. E. El-Hassan \\ Agronomy Department, Faculty of Agriculture, Fayoum University, Fayoum, Egypt.
}

\begin{abstract}
$\mathbf{T}$ WO FIELD experiments were carried out at the Experimental Farm (Demo) of the Faculty of Agriculture, Fayoum University, during 2015/2016 and 2016/2017 seasons, to study the effect of organic and mineral nitrogen fertilizers under foliar application of micronutrients treatments on yield and its components of wheat plants. The experimental design was split-split plot arrangement in randomized complete blocks design with four replications where organic fertilizers were considered in the main plot, nitrogen levels arranged in the sub plot and the subsub plot was foliar application treatments. Results indicated that significant differences between organic fertilizers. Applying poultry manure at the rate of $10 \mathrm{~m}^{3} / \mathrm{fad}$. gave the highest values of all studied characters. Addition, mineral nitrogen fertilizer at $80 \mathrm{~kg} \mathrm{~N} /$ fad led to significantly increased in the all studied characters as compared to using (60kg N/fad and $40 \mathrm{~kg} \mathrm{~N} / \mathrm{fad}$ ). Significant differences were observed among the foliar spraying treatments. Spraying in the mixture micronutrients (Fe, $\mathrm{Mn}$ and $\mathrm{Zn}$ at $100 \mathrm{~g} / 200 \mathrm{~L}$ water/fad) recorded the highest values for all studied characters. From the above results it could be recommended that fertilizing wheat plants by poultry manure at the rate of $10 \mathrm{~m}^{3} /$ fad and foliar spraying with mixture micronutrients ( $\mathrm{Fe}, \mathrm{Mn}$ and $\mathrm{Zn}$ at $100 \mathrm{~g} / 200 \mathrm{~L}$ water/fad) as well as addition $80 \mathrm{~kg} \mathrm{~N} / \mathrm{fad}$, to improve the productivity of wheat yield under newly reclaimed soil conditions in Fayoum Governorate.
\end{abstract}

Keywords: Wheat, Organic fertilizer, Mineral nitrogen fertilizer, Foliar application, Newly reclaimed soil, Yield and its components.

\section{Introduction}

Wheat (Triticum aestivum L.) is the major cereal crop in Egypt. In 2015 wheat cultivated area in Egypt was about 3.3 million faddan which producing about 9.4 million tones. However, it covers less than $55 \%$ of local consumption demand which reflects on the demand import about $45 \%$ of wheat grains (FAO, 2016).

To reduce the gap between production and consumption of wheat crop to confront its consumption exaggerated is an urgent prerequisite. Increasing wheat production is considered as one of the most important strategic goals in order to decrease the great gap between production and human consumption.

Solving these problems needs more hard effects to increase wheat yield. It can happen through some ways. One of that can go through increasing the cultivated area and the second way increasing wheat yield per unit area. Increasing the cultivated area within the old land of Nile Valley, however, in which wheat face severe competition with other winter crops especially clover. So, calls for the cultivation of wheat additional parcels in the newly reclaimed soil.

Growing wheat on the newly reclaimed soil especially calcareous soil faces various problems. This soil has poor physical properties and lacks organic materials, microorganisms; macro and micronutrients. To solve some of such problems, organic material and micronutrients in combination with inorganic fertilizers are needed.

Organic fertilizers reduce the application rate of chemical fertilizers and also help to solve the problem of micro-nutrient deficiency in the soil. Farmyard manure (FYM) is an organic material which its continuous addition to the soil increases its humus content year after year and improving physical and chemical conditions (Agamy et al., 2012). Poultry manure (PM) has long been recognized the most desirable organic fertilizer. It improves soil fertility by adding both major and essential nutrients as well as soil organic matter

"Corresponding author email: aha02@fayoum.edu.eg

DOI: 10.21608/agro.2018.5420.1114

(C)2018 National Information and Documentation Center (NIDOC) 
which improve moisture and nutrient retention (Farhad et al., 2009).

Nitrogen fertilization is an important and essential factor affecting wheat production all over the world especially in Egypt, because most of Egyptian soils contain insufficient nitrogen. Several research conducted in Egypt proved that there is a significant effect of nitrogen levels on most of growth characteristics, yield and yield components. The optimum nitrogen fertilizer levels for wheat in Egypt vary widely in amounts, they ranged between 40 and $120 \mathrm{~kg} \mathrm{~N} /$ fad according to environmental conditions such as type and properties of soil (Mosaad \& Fouda, 2016).

In Egypt, most soils suffer from micronutrients deficiency due to intensive cropping system and no interesting by micronutrients foliar at Egyptian local farmers. The micronutrients play an important role in increasing crop yield. Micronutrients have prominent effects on dry matter, grain yield and straw yield in wheat (Asad \& Rafique, 2000). Iron plays role in biological redox system, enzyme activation and oxygen carrier in nitrogen fixation (Romheld \& Marschner, 1991); Mn utilized in enzyme activation, electron transport and in disease resistance (Burnell, 1988); Zinc is important to membrane integrity and photochromic activities (Shkolnik, 1984).

Therefore, this investigation was established to study the effect of organic and mineral fertilizers under foliar application treatments and their interactions on yield and its components of wheat plants under newly reclaimed soil conditions in Fayoum Governorate.

\section{Materials and Methods}

\section{Experimental site and plant materials}

The present investigation was carried out at the Experimental Farm of Faculty of Agriculture, at Demo, Fayoum University, during the two successive growing seasons 2015/2016 and $2016 / 2017$. The objective of this research was to study the effect of organic and mineral nitrogen fertilizers under foliar application of micronutrients treatments and their interactions on yield and its components of wheat plants.

\section{Layout and experimental design}

A split-split plot design arranged in randomized complete block with four replicates was used.
Three Organic fertilizers treatments $\left(\mathrm{O}_{1}=\right.$ Control, $\mathrm{O}_{2}=$ Farmyard manure at $20 \mathrm{~m}^{3} / \mathrm{fad}$ and $\mathrm{O}_{3}=$ Poultry manure at $10 \mathrm{~m}^{3} / \mathrm{fad}$ ) were considered as the main plot. The sub plot was designated to three nitrogen levels $\left(\mathrm{N}_{1}=40 \mathrm{~kg} \mathrm{~N} / \mathrm{fad}, \mathrm{N}_{2}=60 \mathrm{~kg} \mathrm{~N} / \mathrm{fad}\right.$ and $\mathrm{N}_{3}=80 \mathrm{~kg} \mathrm{~N} /$ fad). Foliar application in the three treatments $\left(\mathrm{F}_{1}=\right.$ Control, $\mathrm{F}_{2}=$ Spraying of water and $\mathrm{F}_{3}=$ Spraying of elements, i.e., Fe, $\mathrm{Mn}$ and $\mathrm{Zn}$ at $100 \mathrm{~g} / 200 \mathrm{~L}$ water/fad) were arranged in the sub-sub plot. The size of each plot was $10.5 \mathrm{~m}^{2}$ (3.5m long and $3.0 \mathrm{~m}$ width).

\section{Cultural practices}

Wheat variety Sakha 93 was obtained from the Wheat Department, Field Crops Institute Research, Agricultural Research Center, Giza, Egypt. Wheat grains variety Sakha 93 were sown at seed rate of $50 \mathrm{~kg} / \mathrm{fad}$ in rows $15 \mathrm{~cm}$ and sowing date was November 24 and harvested in May $10^{\text {th }}$ in both seasons. The preceding summer crop was maize (Zea mays L.) in both seasons. $\mathrm{N}$ fertilizer was added as ammonium nitrate $(33.5 \% \mathrm{~N})$. Phosphorus fertilizer was applied in the form of calcium superphosphate $\left(15.5 \% \mathrm{P}_{2} \mathrm{O}_{5}\right)$ at the rate of $150 \mathrm{~kg} \mathrm{P}_{2} \mathrm{O}_{5} /$ fad, added during the soil preparation. Potassium fertilizer was added in the form of potassium sulphate $\left(48 \% \mathrm{~K}_{2} \mathrm{O}\right)$ at the rate of $50 \mathrm{~kg}$ $\mathrm{K}_{2} \mathrm{O} / \mathrm{fad}$, added in one dose before first irrigation. Irrigation was carried out every two weeks. Other cultural practices were followed as recommended.

\section{Soil analysis}

Soil samples were taken from 0.0 to $60 \mathrm{~cm}$ depth. Samples were air-dried, ground, sieved through a $2 \mathrm{~mm}$ sieve and analyzed to obtain the physical and chemical properties of the soil.Mechanical analysis was determined according to the international pipette method as described by Piper (1950).

The organic matter was determined by Walkley and Black method as described by Hesse (1971). PH value was measured in the 1:2:5 soilwater suspension using Beckman glass ectrode, as described by Black et al. (1965). Electrical conductivity was measured in saturation extract of soil paste in $\mathrm{dS} \mathrm{m}^{-1}$ as described by Jackson (1967).

The total nitrogen was determined using the conventional method of kjeldahl (Black et al, 1965). Available phosphorus was calorimetrically determined at a wave length of $725 \mathrm{n} . \mathrm{m}$ in the sodium bicarbonate saturations as described by Olsen \& Sommers (1982). 
The available potassium was determined by a flame photometer in the extraction with $1.0 \mathrm{~N}$ ammonium acetate at $\mathrm{pH} 7$ according to Knudsen et al. (1982). Physical and chemical analyses of the experimental soil are presented in Table 1.

Samples from the two organic fertilizers (farmyard manure and poultry manure) were collected at random before planting to measure the (NPK) as shown Table 2.

Field sampling and data collection:

At harvest, five guarded plants were taken at random from each sub-sub plot in the four replications to determine the agronomic data:

1- Plant height at harvest $(\mathrm{cm})$.

2- Number of tillers/plant.

3- Number of spikes/plant.

4- Spike length (cm).

5- Number of spikelets/spike.

6- Number of grains/spike.

7- Weight grain/plant (g).

8-1000-grain weight $(\mathrm{g})$.

9- Biological yield (ton/fad) which was calculated on the plot bases.

10- Grain yield (ton/fad) which was calculated on the plot bases.

11- Harvest index (\%) which was estimated as: Grain yield/biological yield x 100 .

\section{Statistical analysis}

Data were subjected to the proper statistical analysis as mentioned by Snedecor \& Cochran (1980). Treatment means were compared using the Least Significant Difference (LSD) test at a probability level of $(\mathrm{P} \leq 0.05)$. The combined data across the two seasons were subjected to an ANOVA using MSTAT-C computer software.

\section{Results and Discussion}

Effect of organic fertilizers

Results in Table 3 indicate that organic fertilization treatments had a significant effect on all characters under study in the combined data of the two successive seasons. Application of organic fertilizers such as farmyard or poultry manure caused significant increases in all studied characters as compared to control treatment (without organic fertilization).Using poultry manure at the rate of $10 \mathrm{~m}^{3} / \mathrm{fad}$ recorded the highest values for yield and its components. The increase in studied characters, due application of both farmyard and poultry manure, may be attributed to the role played by both in enhancement of plant growth due to enrichment of soil (increase in soil fertility, improvement of soil physical properties and water holding capacity, reduced the soil $\mathrm{pH}$ especially in the rhizosphare, decrease of the effect of salinity stress) and providing wheat plants with necessary growth nutrients. These results are in coincidence with those reported by Ghafoor et al. (2015), Jan \& Boswal (2015) and Attia \& Shaalan (2016).

TABLE 1. Some physical and chemical analysis of the experimental site "Demo Experimental Farm" (combined data over 2015/2016 and 2016/2017 seasons).

\begin{tabular}{|c|c|c|c|c|c|c|c|c|c|c|c|c|c|}
\hline \multicolumn{14}{|c|}{ Physical analysis } \\
\hline \multirow{2}{*}{\multicolumn{2}{|c|}{ Depth (cm) }} & \multicolumn{8}{|c|}{ Particle size distribution } & \multirow{2}{*}{\multicolumn{2}{|c|}{$\begin{array}{c}\text { Bulk density } \\
\left(\mathrm{g} / \mathrm{cm}^{3}\right)\end{array}$}} & \multirow{2}{*}{\multicolumn{2}{|c|}{$\begin{array}{c}\text { Hydraulic } \\
\text { conductivity }(\mathrm{cm} / \mathrm{h})\end{array}$}} \\
\hline & & \multicolumn{2}{|c|}{ Sand(\%) } & \multicolumn{2}{|c|}{ Silt(\%) } & \multicolumn{2}{|c|}{ Clay $(\%)$} & \multicolumn{2}{|c|}{ Texture class } & & & & \\
\hline \multicolumn{2}{|l|}{$0-20$} & \multicolumn{2}{|c|}{72.50} & \multicolumn{2}{|r|}{12.90} & \multicolumn{2}{|c|}{14.60} & \multicolumn{2}{|c|}{ Sandy loam } & \multicolumn{2}{|c|}{1.53} & \multicolumn{2}{|r|}{2.70} \\
\hline \multicolumn{2}{|l|}{$20-40$} & \multicolumn{2}{|c|}{74.20} & \multicolumn{2}{|r|}{12.40} & \multicolumn{2}{|r|}{13.40} & \multicolumn{2}{|c|}{ Sandy loam } & \multicolumn{2}{|r|}{1.56} & \multicolumn{2}{|r|}{2.47} \\
\hline $40-60$ & & \multirow{2}{*}{\multicolumn{2}{|c|}{$\begin{array}{l}73.20 \\
73.30\end{array}$}} & & 12.10 & \multirow{2}{*}{\multicolumn{2}{|c|}{$\begin{array}{l}14.70 \\
14.23\end{array}$}} & \multicolumn{2}{|c|}{ Sandy loam } & \multicolumn{2}{|r|}{1.58} & \multicolumn{2}{|r|}{2.38} \\
\hline \multicolumn{2}{|l|}{ Mean } & & & & 12.47 & & & & idy loam & \multicolumn{2}{|r|}{1.56} & \multicolumn{2}{|r|}{2.52} \\
\hline \multicolumn{14}{|c|}{ Chemical analysis } \\
\hline \multirow{2}{*}{$\begin{array}{l}\text { Depth } \\
(\mathrm{cm})\end{array}$} & \multirow{2}{*}{ pH } & $\mathbf{E C}_{\mathrm{e}}$ & \multicolumn{4}{|c|}{ Soluble cations (meq/L) } & & Solu & le anions & $(\mathrm{meq} /$ & $/ / \mathrm{L})$ & & Organic \\
\hline & & dS $\mathbf{m}^{-1}$ & $\mathbf{C a}^{++}$ & $\mathbf{M g}^{++}$ & $\mathbf{N a}^{+}$ & $\mathbf{K}^{+}$ & & $\mathrm{O}_{3}=$ & $\mathrm{HCO}_{3}^{-}$ & $\mathrm{Cl}^{-}$ & $\mathrm{SO}_{4}=$ & 0 & matter\% \\
\hline $0-20$ & 7.70 & 4.01 & 13.10 & 10.00 & 17.20 & 1.20 & & 00 & 3.20 & 25.10 & 13.30 & 4.50 & 0.76 \\
\hline $20-40$ & 7.60 & 3.30 & 10.00 & 8.70 & 14.10 & 1.00 & & 00 & 3.00 & 20.20 & 10.70 & 5.02 & 0.68 \\
\hline $40-60$ & 7.80 & 3.00 & 9.20 & 8.00 & 12.20 & 1.10 & & .00 & 3.30 & 19.50 & 7.60 & 4.25 & 0.66 \\
\hline Mean & 7.70 & 3.40 & 10.80 & 8.90 & 14.50 & 1.10 & & .00 & 3.20 & 21.60 & 10.50 & 4.59 & 0.70 \\
\hline
\end{tabular}

TABLE 2. Chemical analysis of farmyard manure and poultry manure used in both seasons.

\begin{tabular}{llll}
\hline Samples & N\% & P\% & K\% \\
\hline Farmyard manure & 0.90 & 0.20 & 3.66 \\
Poultry manure & 3.30 & 0.60 & 2.26 \\
\hline
\end{tabular}




\section{Effect of nitrogen levels}

Data presented in Table 3 reveal that yield and its components were significantly increased with increasing nitrogen levels in the combined data of the two successive seasons. The maximum means of yield and its components were produced from fertilizing wheat plants with $80 \mathrm{~kg} \mathrm{~N} /$ fad as compared to $60 \mathrm{~kg} \mathrm{~N} /$ fad or $40 \mathrm{~kg}$ $\mathrm{N} / \mathrm{fad}$. The increase in these characters may be due to nitrogen fertilization role inactivation cells division, size, elongation, also metabolic and photosynthesis processes, therefore improving productivity of yield. Also, increased nitrogen fertilization led to increase production of wheat yield due to strong response to additions of nitrogen, which is regarded as the main element in the construction of amino acids, proteins and enters in many physiological processes in plant. These results are in harmony with those recorded by Abd El-Lattief (2013), Abou-Keriasha \& Essa (2014), Bavar et al. (2016) and El-Temsah (2017).

\section{Effect of foliar application}

Foliar application with the applied micronutrients had a significant effect on all characters under study in the combined data of the two successive seasons (Table 3). The mixtures of three micronutrients (Fe, Mn and $\mathrm{Zn}$ ) at the rate of $100 \mathrm{~g} / 200 \mathrm{~L}$ water/fad, significantly ranked first and produced the highest values of yield as well as all its components as compared to control treatment (without spraying). Spraying of water at the same times came the second rank after mentioned treatment with significant differences. These results might be due to foliar application twice with mixture micronutrients (Fe, Mn and $\mathrm{Zn)}$ may be due to the role of micronutrients in increasing meristematic activity reflecting increases in yield and its components. These results were parallel with those reported by Ali et al. (2013), Mekkei et al. (2014), Gomaa et al. (2015), Gosavi et al. (2017) and Zaki et al. (2018).

\section{Interaction effects:}

Results in Table 4 showed that the effect of OxN interaction was significant on plant height, number of spikes/plant, spike length, weight of grains/plant, biological yield, grain yield and harvest index. While, number of tillers/plant, number of spikelets/spike, number of grains/ spike and 1000 grain weight were insignificant. The interaction $\left(\mathrm{O}_{3} \mathrm{xN}_{3}\right)$ recorded the highest values of yield, its components in the combined data of the two successive seasons. These results are in agreement with these obtained by Ahmad et al. (2013), Khan et al. (2016), Khatab et al. (2016) and Zhang et al. (2017).

Data in Table 5 revealed that $\mathrm{OxF}$ interaction effect was significant on number of tillers/ plant, number of spikes/plant, spike length, number of grains/spike, weight of grains/plant, biological yield, grain yield and harvest index. However, plant height, numbers of spikelets/ spike and 1000 grain weight were insignificant. The interaction $\left(\mathrm{O}_{3} \mathrm{xF}_{3}\right)$ gave the highest values of all studied characters in the combined data of the two successive seasons. These results are in accordance with the results of Radwan et al. (2015) and Nadim et al. (2016),

As shown in Table 6 reported that the effect of $\mathrm{NxF}$ interaction was significant on number of tillers/plant, number of spikes/plant, spike length, number of grains/spike, weight of grains/ plant, 1000 grain weight, biological yield, grain yield and harvest index. However, plant height and numbers of spikelets/spike were insignificant. The interaction $\left(\mathrm{N}_{3} \mathrm{xF}_{3}\right)$ produced the highest values of all studied characters in the combined data of the two successive seasons. These results came in the similar point view with those reported by Faizy et al. (2017).

From obtained results in Table 7 indicated that $\mathrm{OxNxF}$ interaction effect was significant on number of tillers/plant, spike length, weight of grains/plant, biological yield, grain yield and harvest index. However, plant height, number of spikes/plant, numbers of spikelets/spike number of grains/spike, and 1000 grain weight were insignificant. The interaction $\left(\mathrm{O}_{3} \mathrm{xN}_{3} \mathrm{x}\right.$ $\mathrm{F}_{3}$ ) recorded the highest values of all studied characters in the combined data of the two successive seasons. Similar obtained by AlDulaimi et al. (2015).

\section{Conclusion}

It can be concluded that fertilizing wheat plants by poultry manure at the rate of $10 \mathrm{~m}^{3} / \mathrm{fad}$ and foliar spraying with mixture micronutrients (Fe, Mn and $\mathrm{Zn}$ at $100 \mathrm{~g} / 200 \mathrm{~L}$ water/fad) with addition $80 \mathrm{~kg}$ $\mathrm{N} /$ fad may be the best combination to improve the productivity of wheat under newly reclaimed soil conditions in Fayoum Governorate. 


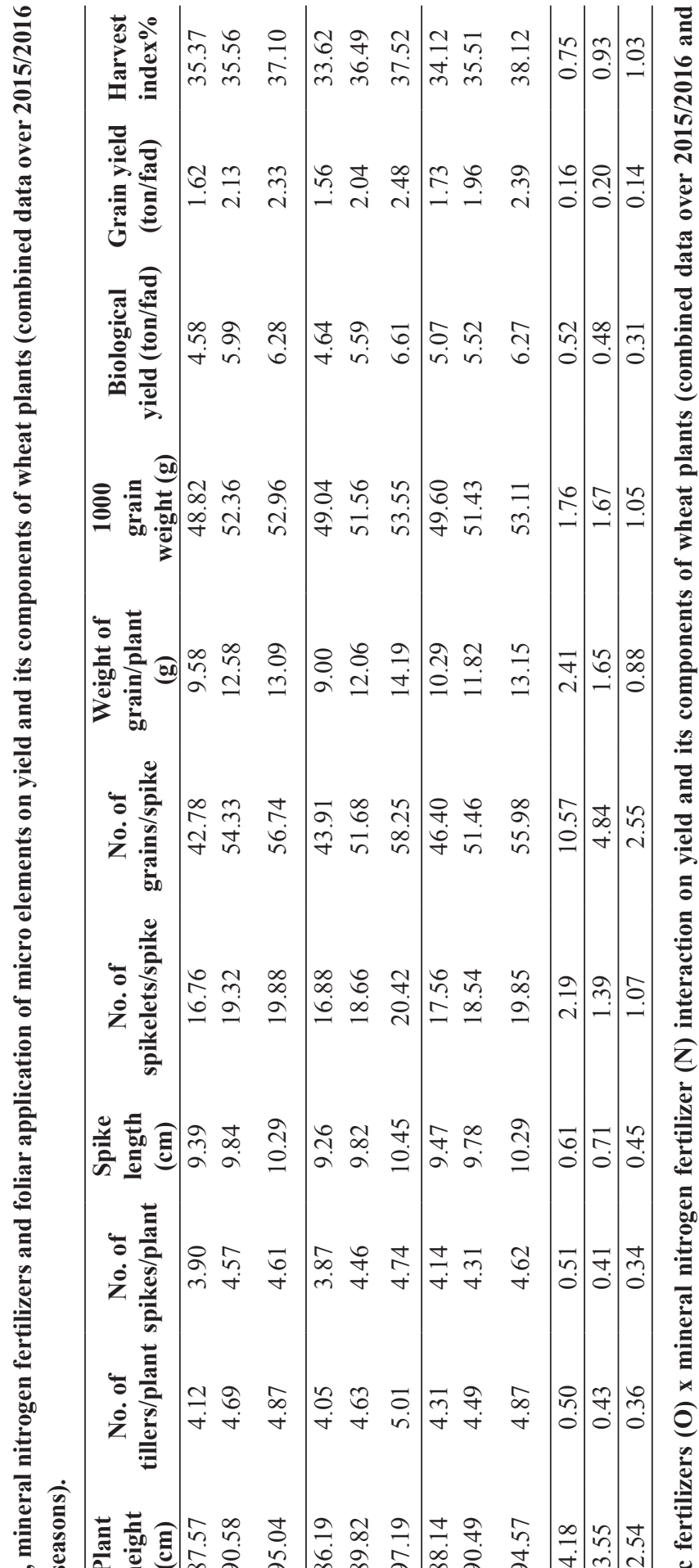

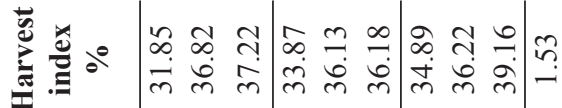

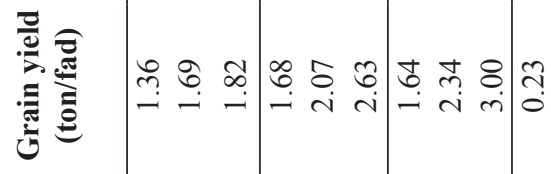
를

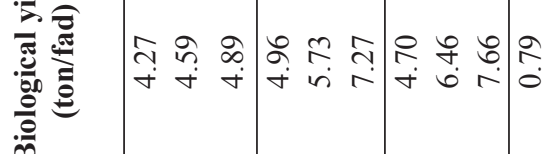

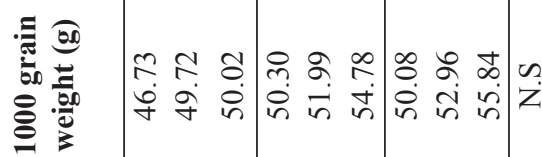

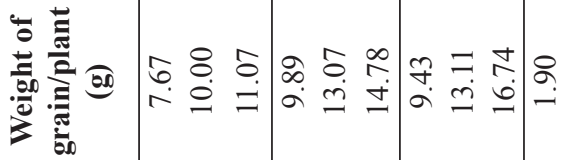

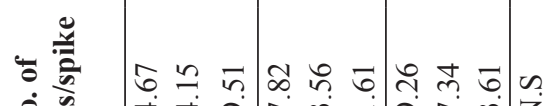

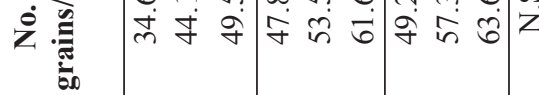

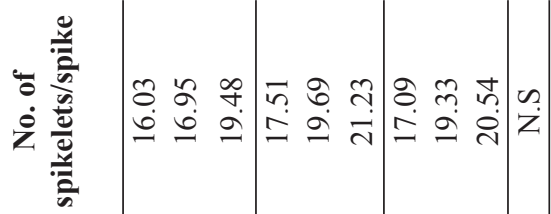

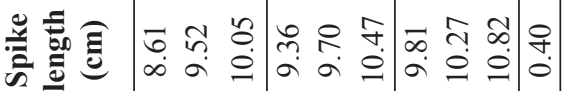

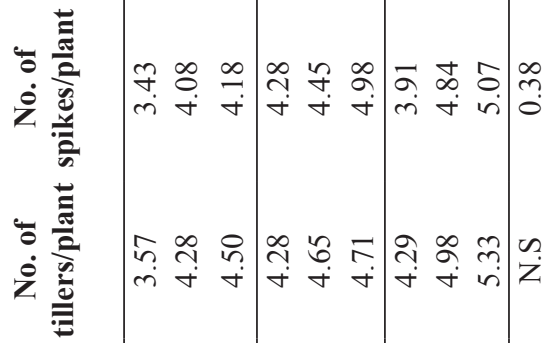
颉

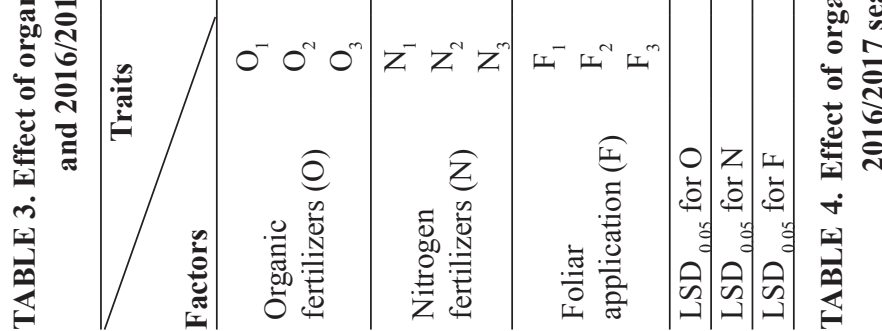

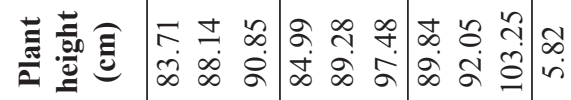

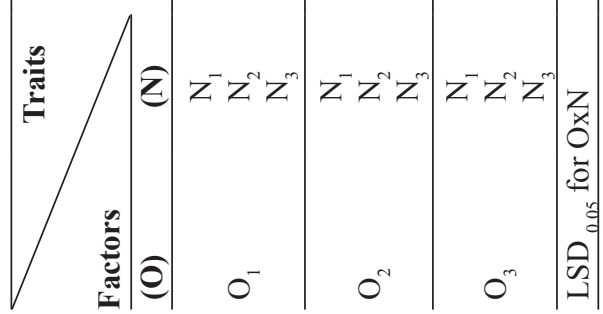




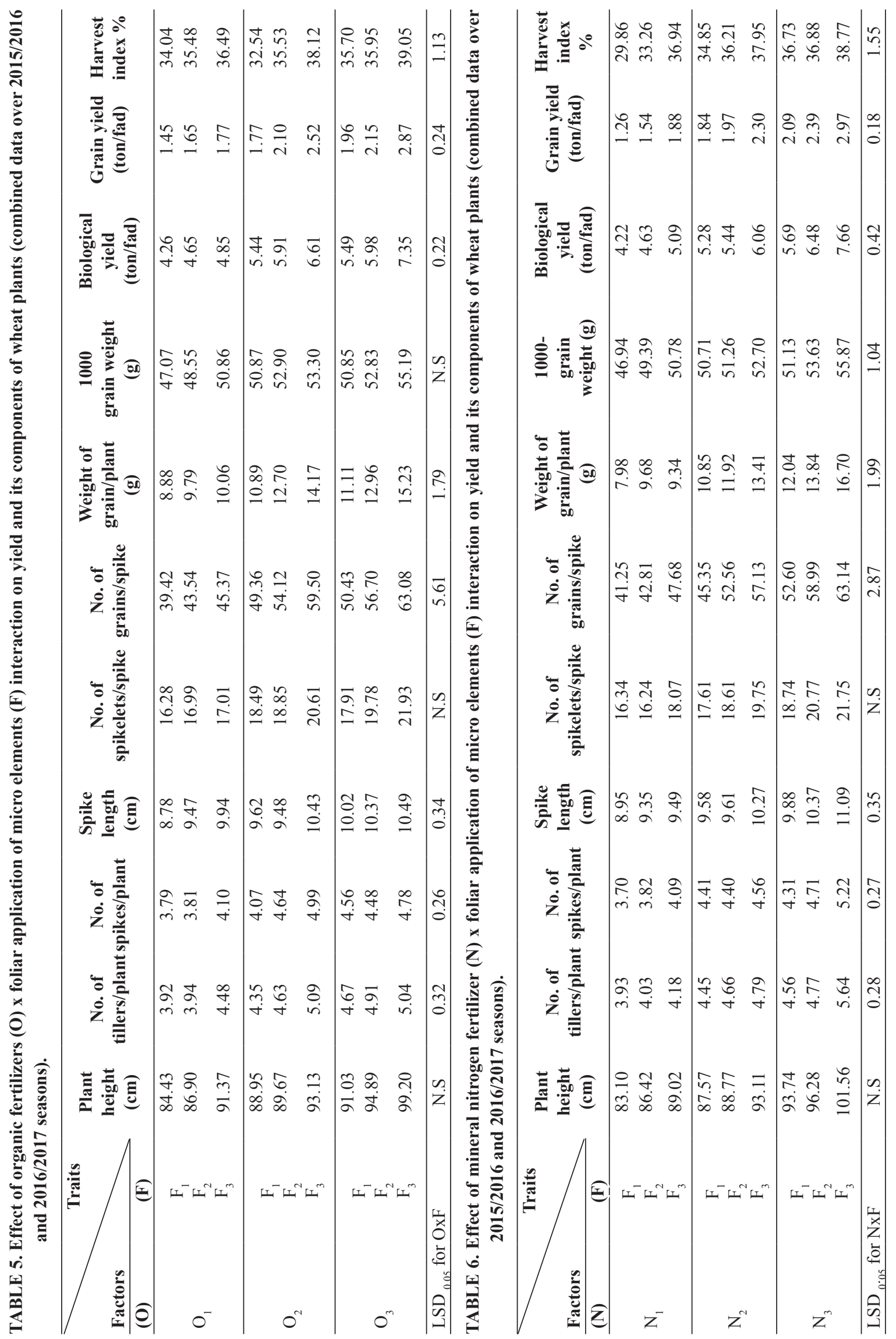

Egypt. J. Agron. Special Issue (2018) 


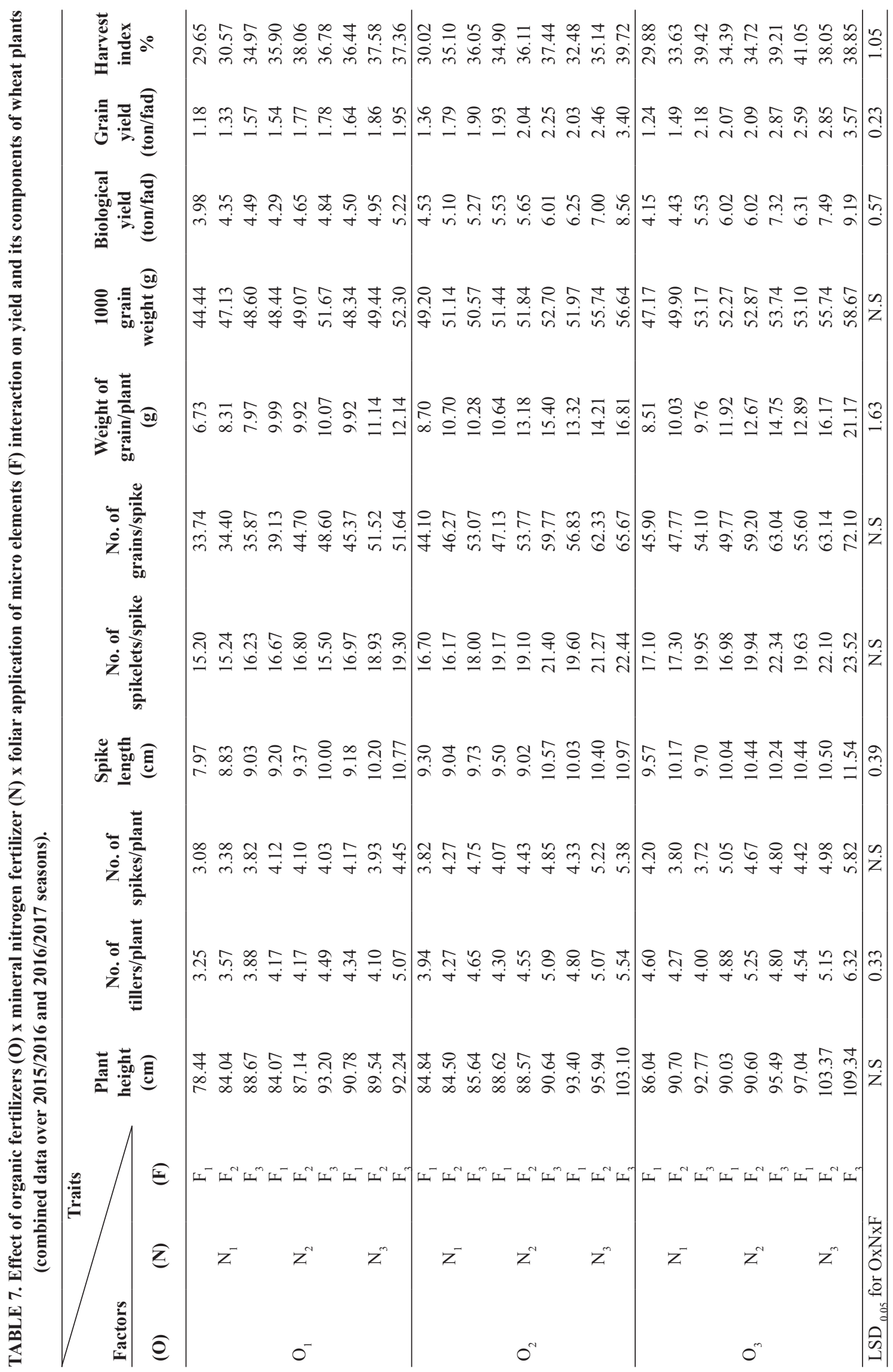




\section{References}

Abd El-Lattief, E.A. (2013) Impact of integrated use of bio and mineral nitrogen fertilizers on productivity and profitability of wheat (Triticum aestivum L.) under Upper Egypt condition. Inter. J. Agron. Agric. Res. 3(12), 67-73.

Abou-Keriasha, M.A. and Essa, Nadia M.A. (2014) Mineral nitrogen fertilizer and compost effects on wheat and maize yields in crop sequences including intercropped legumes. Egypt. J. Agron. 36(2), 147-163.

Agamy, R.A., Mohamed, G.F. and Rady, M.M. (2012) Influence of the application of fertilizer type on growth, yield, anatomical structure and some chemical components of wheat (Triticum aestivum L.) grown in newly reclaimed soil. Australian J. Basic Appl. Scie. 6(3), 561-570.

Ahmad, M., Afzal, M., Ahmad, A., Ahmad, A.U.H. and Azeem, M.I. (2013) Role of organic and inorganic nutrient sources in improving wheat crop production. Cercetari Agronomice in Moldova, 46(1), 15-21. doi: https://doi.org/10.2478/v10298-012-0071-0

Al-Dulaimi, O.I.M., Al-Rawi, A.R.M., Al-Qaisi, E.K.K. and El-Moursy, Rasha S.A. (2015) Response of some wheat cultivars to organic, mineral and foliar fertilization. J. Plant Production, Mansoura Univ. 6(10), 1755-1770

Ali, M.A., Tariq, N.H., Ahmed, N., Abid, M. and Rahim, A. (2013) Response of wheat (Triticum aestivum L.) to soil applied boron and zinc fertilizers under irrigated conditions. Pak. J. Agril. Engg. Vet. Sci., 29(2), 114-125.

Asad, A. and Rafique, R. (2000) Effect of zinc, copper, manganese and boron on the yield and yield components of wheat crop in Tehsil Peshawar. Pakistan J. Biol. Sci. 3, 1615-1620.

Attia, M.A. and Shaalan, A.M. (2016) Response of wheat (Triticum aestivum L.) to humic acid and organic fertilizers application under varying Siwa Oasis conditions. J. Agric. Veteri. Sci. 9(1), 81-86.

Bavar, M., Abad, H.H.S. and Noormohamadi, Gh. (2016) The effect of different levels of nitrogen on yield and yield components of rain fad wheat in two regions of north khorasan. Open J. Ecolo. 6, 443-451.
Black, C.A., Evans, D.D., White, J.L., Ensminmager, L.E. and Clarrk, F.E. (1965) In: "Methods of Soil Analysis", Part 2. Amer. Soc. Agron. Inc., Publisher Madison, Wisconson, USA.

Burnell, J.N. (1988) The biochemistry of manganese in plants. In: "Manganese in Soils and Plants", Graham, R.D., Hannam, R.J. and Uren, N.C. (Ed.), pp. 125-137. Kluwar Acad. Public. Dordrecht.

El-Temsah, M.E. (2017) Response of wheat yield, its components and technological characteristics to different nitrogen rates and planting methods. Egypt. J. Agron. 39(3), 421-429.

Faizy, S.E.D., Mashali, S.A., Youssef, S.M. and Elmahdy, Shaimaa M. (2017) Study of wheat response to nitrogen fertilization, micronutrients and their effects on some soil available macronutrients. J. Sus. Agric. Sci. 43(1), 55-64.

Farhad, W., Saleem, M.F., Cheema, M.A. and Hammad, H.M. (2009) Effect of poultry manure levels on the productivity of springmaize (Zea mays L.). The Journal of Animal and Plant Sciences, 19(3), 122-125.

FAO (Food and Agriculture Organization of the United Nations) (2016) FAOSTAT: World Crop Production Data.

Ghafoor, A.M.R., Sarkawet, T.A. and Mohammed, Q.A. (2015) Influence of different organic fertilizers on growth and yield of wheat. American-Eurasian J. Agric. Environ. Sci. 15(6), 1123-1126.

Gomaa, M.A., Radwan, F.I., Kandil, E.E. and El-Zweek, Seham M.A. (2015) Effect of some macro and micronutrients application methods on productivity and quality of wheat (Triticum aestivum L.). Middle East J. Agric. 4(1), 1-11.

Gosavi, A.B., Deolankar, K.P., Chaure, J.S. and Gadekar, D.A. (2017) Response of wheat for NPK foliar sprays under water stress condition. Intern. J. Chemi. Studies, 5(4), 766-768.

Hesse, P.R. (1971) "A Text Book of Soil Chemical Analysis". John Murry (Publisher) Ltd, 50 Albemarle Street, London.

Jackson, M.L (1967) "Soil Chemical Analysis", pp.144197. Hall of Indian, New Delhi.

Jan, K. and Boswal, M.V. (2015) Influence of jinong 
(organic liquid fertilizer) on seedling germination and growth and its comparison with bio-fertilizer on yield of bread wheat (Triticum aestivum L.). Inter. J. Advan. Techn. Engin. And Sci. 3(Special Issue No. 1), 2348-7550.

Khan, A.Z., Muhammad, H., Muhammad, A., Khalil, S.K., Shah, Z. and Amin, R. (2016) Phenology, yield and nutrient uptake efficiency of wheat as affected by organic and inorganic nitrogen fertilizer alone and in combination with effective microorganism. Middle East J. Agaric. Res. 5(4), 435-441.

Khatab, A.K., Hemeid, Nadia M. and Mohamed, Amira A. (2016) Impact of mineral, organic and bio fertilizers on growth, yield and quality of fodder beet under sandy soil conditions in north sinai. J. Soil Sci. Agric. Eng., Mansoura Univ. 7(5), 345-352.

Knudsen, D., Peterson, G.A. and Part, P.F. (1982) Lithium, sodium and potassium, Chapter 13. In: "Methods of Soil Analysis, Part 2. Chemicals and Microbiological Properties", Agron. No. 92 ${ }^{\text {nd }}$ ed., Soil Sci. Amer. Madison, Wis., USA.

Mekkei, M.E.R. and El Haggan, Eman A.M.A. (2014) Effect of $\mathrm{Cu}, \mathrm{Fe}, \mathrm{Zn}$ foliar application on productivity and quality of some wheat cultivars (Triticum aestivum L.). J. Agric., Food Appl. Sci. 2(9), 283-291.

Mosaad, I.S. and Fouda, K.F. (2016) Effect of potassium and nitrogen fertilization on some macronutrients utilization efficiency by wheat. Egypt. J. Soil. Sci. 56(3), 373- 384 .

Nadim, M.A., Baloch, M.S., Khan, E.A., Khakwani, A.A. and Waseem, K. (2016) Integration of organic, synthetic fertilizers and micronutrients for higher growth and yield of wheat. Sarhad J. Agric. 32(1), 9-16.
Olsen, S.R. and Sommers, L.F. (1982) "Methods of Soil Analysis Part 2. Chemicals and Microbiological Properties", pp. 403-430. Agron. Madison, Wis., USA.

Piper, C.S. (1950) "Soil and Plant Analysis". Inter. Sci. Publ. Inc. New York.

Radwan, F.I., Gomaa, M.A., Rehab, I.F. and Adam, Samera I.A. (2015) Impact of humic acid application, foliar micronutrients and bio-fertilization on growth, productivity and quality of wheat (Triticum aestivum L.). Middle East J. Agric. 4(2), 130-140

Romheld, V. and Marshner, H. (1991) Genotypic differences among graminaceous species in release of phytosiderophores and uptake of iron of phytosiderophores. Plant Soil, 123, 147-153.

Shkolnik, M.Y. (1984) "Trace Elements in Plants". Elsevier, Amsterdam.

Snedecor, G.W. and Cochran, W.G. (1980) "Statistical Methods", $7^{\text {th }}$ ed., Iowa State Univ.

Zaki, Nabila M., Hassanein, M.S. and Ahmed, Amal G. (2018) Effect of foliar nutrition grow vit on yield and yield components of two wheat cultivars. Middle East J. Agric. Res. 7(2), 248-253.

Zhang, H., Xinyang, Y., Zhongyu, J., Zheng, W., Bingnian, Z. and Ziyan, L. (2017) Improving grain yield and water use efficiency of winter wheat through a combination of manure and chemical nitrogen fertilizer on the Loess plateau, China. J. Soil Sci. Plant Nutr. 17(2), 461-474.

(Received 4/ 10/2018; accepted 28/11/2018) 


\section{تحسين إنتاجية القمح بتطبيق أنواع مختلفة من الأسمدة تحث ظروف الأراضي المستصلحة \\ فوزي سيد عبد السميع، محمد عويس أحمد راضي، أيمن حمدي علي مهذي و يسرا مصطفي النحاس الحسن

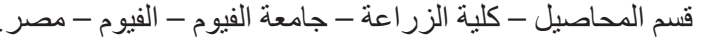

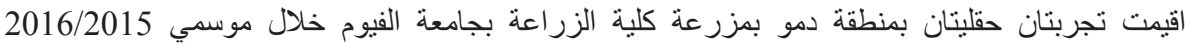

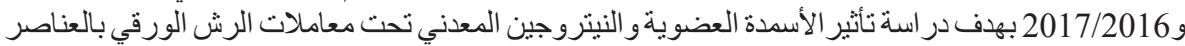

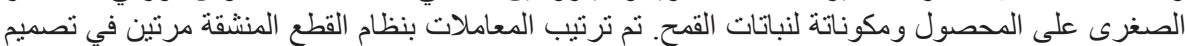

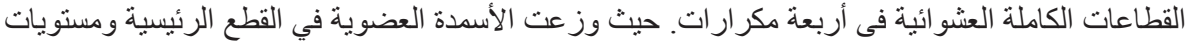

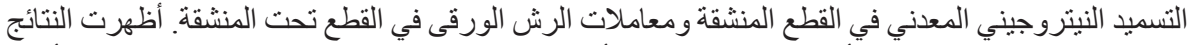

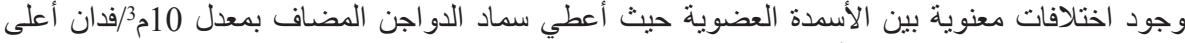

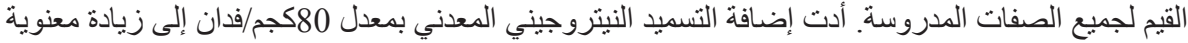

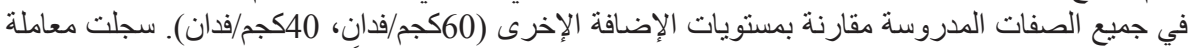

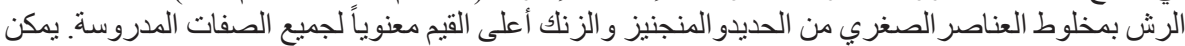

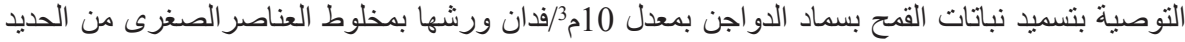

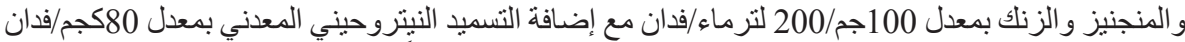
لتحسين إنتاجية محصول القمح تحت ظروف الأر اضي المستصلحة حديثاً بمنطقة دمو بمحافظة الفيوم. 